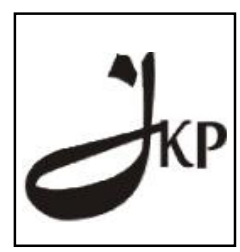

Jurnal Konseling dan Pendidikan

ISSN Cetak: 2337-6740 - ISSN Online: 2337-6880

http://jurnal.konselingindonesia.com

Volume 3 Nomor 2, Juni 2015, HIm 1-7

\title{
Kolaboratif: Kerangka Kerja Konselor Masa Depan
}

\author{
Afdal $^{1 *}$ \\ ${ }^{1}$ Fakultas Ilmu Pendidikan, Universitas Negeri Padang
}

\begin{abstract}
The successful implementation of guidance and counseling in schools is not only the duty of counselor alone, but further a common task among school personnel (both the principal, teachers, class guardian, administration officials and other students) and the school environment (parents, communities, and others). This paper presents ideas with regard to the importance of establishing collaborative with other persons to help optimal students development.
\end{abstract}

Keyword: guidance and counseling, collaborative

Copyright (C) 2015 IICE - Multikarya Kons (Padang - Indonesia) - All Rights Reserved Indonesian Institute for Counseling and Education (IICE) Multikarya Kons

\section{PENDAHULUAN}

Sistem pendidikan di Indonesia jauh-jauh hari sudah menetapkan layanan bimbingan dan konseling sebagai bagian utuh dari pendidikan untuk mewujudkan siswa yang mandiri dan berkembang secara optimal. Dalam praktiknya, layanan bimbingan dan konseling itu mengacu kepada pola pelayanan bimbingan dan konseling yang dikenal dengan bimbingan dan konseling komprehensif. Pola tersebut mengandung arti bahwa layanan bimbingan dan konseling diselenggarakan secara terpadu dan berkesinambungan pada semua aspek dan jenjang pendidikan, dan tidak hanya melayani siswa di sekolah saja, akan tetapi juga memberikan layanan bimbingan dan konseling di lingkungan luar sekolah, seperti lingkungan keluarga serta lingkungan masyarakat.

Lingkungan keluarga menjadi perhatian layanan bimbingan dan konseling karena lingkungan keluarga merupakan lingkungan yang penting dalam perkembangan individu, mengingat lingkungan keluarga merupakan lingkungan sosial dan pendidikan pertama yang berpengaruh terhadap pembentukan sikap, keyakinan dan kepribadian individu, yang akan berpengaruh bagi kehidupannya dimasa mendatang.

Studi yang dilakukan berkenaan dengan peran lingkungan keluarga dalam usaha membantu siswa mempersiapkan dan merencanakan karirnya, banyak orang tua yang beranggapan bahwa urusan persiapan dan perencanaan karir anaknya adalah urusan guru. Ada juga orangtua yang berpendapat bahwa urusan mereka hanyalah mempersiapkan dari segi materi yang dibutuhkan anaknya dalam usaha mempersiapkan atau merencanakan karir mereka masing-masing. Sedangkan urusan lain berkenaan dengan pendidikan (termasuk perkembangan karir anak) sepenuhnya diserahkan kepada guru atau sekolah. Selain menyerahkan urusan pendidikan kepada guru, terdapat juga orangtua yang menyerahkan urusan pendidikan di lingkungan keluarga

\footnotetext{
* Telp atau Alamat Email Koresponden :

* ${ }^{1}$ Tel.: +6285263084498. E-mail address : afdal@konselor.org
} 
kepada pembantu, sehingga tercipta hubungan emosional yang lebih dalam dengan pembantu dibandingkan dengan orangtua kandungnya sendiri (Kompasiana, 24 September 2011).

Permasalahan tersebut menjadi bertambah ketika guru BK/konselor yang memahami dan mengerti secara mendalam tentang anak dan perkembangan karir tidak melakukan kegiatan kolaborasi/kerja sama dengan orangtua untuk secara bersama mewujudkan perkembangan karir anak yang optimal sehingga mampu mengambil keputusan secara tepat dan mandiri dalam hal pendidikan dan karirnya di masa akan datang, termasuk dalam hal kerjasama dengan orangtua. Hal ini tentunya memerlukan perhatian khusus dari para ahli bimbingan dan konseling, mengingat kolaboratif dengan orangtua merupakan salah satu bagian kompetensi yang harus dimiliki oleh guru BK/konselor, seperti yang tercantum dalam kompetensi konselor dalam bidang mengembangkan pribadi dan profesionalitas secara berkelanjutan dengan mengimplementasikan kolaborasi intern di tempat bekerja yaitu bekerja sama dengan pihak-pihak terkait di dalam tempat bekerja termasuk di dalamnya dengan orang tua (Depdiknas, 2008:164).

Permasalahannya sekarang adalah pelaksanaan kolaboratif dengan orangtua bukanlah menjadi bagian yang penting dalam pelaksanaan keseluruhan program oleh guru BK/konselor di sekolah. Wawancara awal yang dilakukan terhadap 3 (tiga) orang guru BK/konselor di SMA kota Padang pada tanggal 18-20 September ditemukan bahwa pada umumnya guru BK/konselor tidak melakukan kegiatan kolaboratif/kerja sama dalam hal perencanaan karir anak, termasuk di dalamnya dalam hal merencanakan dan mengevaluasi program perencanaan karis siswa secara bersama. Hal ini juga menimbulkan persepsi seolah-olah orangtua melepaskan semua tanggung jawab pendidikan kepada guru dan guru juga dipersepsi sebagai orang yang paling bertanggung jawab terhadap pendidikan siswa. Termasuk dalam hal pengembangan karir, nilai-nilai keluarga (seperti kehangatan dan kelekatan) tidak terjalin dengan baik antara anak dan orangtua karena berbagai hal sehingga berpotensi memunculkan permasalahan siswa dalam bidang karir (seperti tidak mampu merencanakan karir yang tepat sesuai dengan potensi diri dan tuntutan lingkungan dan sebagainya).

\section{KONSEP DASAR KOLABORATIF}

Untuk mencapai perkembangan siswa yang optimal, proses pendidikan tidak hanya bisa diserahkan pada satu bidang kegiatan (seperti hanya pada pembelajaran bidang studi atau bidang bimbingan dan konseling) akan tetapi merupakan kerjasama yang baik antar komponen pendidikan untuk mencapai tujuan bersama pendidikan. Kerjasama yang baik itu tidak hanya dilakukan dalam internal sekolah saja akan tetapi juga melibatkan berbagai pihak yang memiliki perannya masing-masing. Kerjasama tersebut dilakukan dalam bentuk kegiatan kolaboratif.

Penggunaan istilah kolaboratif berasal bahasa Inggris yaitu collaborative yang berarti bekerja sama atau collaboration yang berarti kerja sama. Dalam pengertian yang lebih luas, Frans \& Bursuck (1996:74) mendefenisikan kolaboratif sebagai gaya/cara yang dipilih oleh para profesional untuk pencapaian tujuan bersama. Hal ini mengisyaratkan bahwa individu yang terlibat dalam kegiatan kolaboratif memiliki tujuan yang sama, tidak boleh berbeda-beda, sehingga membutuhkan adanya mekanisme perencanaan, pelaksanaan, evaluasi dan tindak lanjut secara bersama sehingga tujuan bersama yang akan dicapai dapat terwujud. Hal ini sesuai dengan pendapat Idol \& Baran (dalam Schmidt, 2003:60) yang menyatakan bahwa in collaborative, planning and implementing are joint effort. Ini berarti dalam pelaksanaan kolaboratif yang efektif, kegiatan perencanaan dan pelaksanaan merupakan usaha bersama.

Istilah kolaboratif dalam ilmu konseling dan psikoterapi menurut Bertolino \& O’Hanlon (2001) terjadi dalam perkembangan yang cukup panjang, dengan menguraikan perkembangan pola layanan bimbingan dan konseling kolaboratif ke dalam tiga pola, yakni (1) pola acuan yang memfokuskan pada fisik, patologi dan pengalaman masa lalu yang didominasi oleh teori psikoanalisa, psikodinamik dan psikiatri biologis dengan didasari patologi. Pola layanan acuan ini lebih mengutamakan alasan hasil berpikir analitik, berdasarkan prinsip-prinsip klasik, peran pengkondisian, dan kontribusi analisis secara mendalam dari psikoanalisis. (2) pola layanan yang mengubah pandangan dari intrafisik dan tindakan masa lalu menuju tindakan masa kini. Dalam konseling keluarga, istilah intrafisik merupakan interaksi dalam mempelajari hubungan, yang berarti bahwa bentuk setiap kepribadian bukan karena pengaruh dari lamanya interaksi dengan orang lain, tetapi dari pola komunikasi, keluarga, hubungan sosial, rangsangan dan tanggapan. Pola ini dikembangkan tahun 1950. Dalam pola ini, konselor bertanggungjawab membantu memecahkan masalah klien dengan menentukan ketidakberfungsian hubungan melalui aspek-aspeknya seperti struktur keluarga, peran, aturan, batasan dan intervensi untuk perubahan, gangguan, pola bertindak dan interaksi, (3) pola layanan yang berbasis kolaboratif dimulai dari suatu hal yang telah dikembangkan dan 
dianalisis yang dimulai sejak akhir tahun 1970 dan awal 1980. Pola ini pada awalnya dilakukan oleh terapis keluarga yang menggunakan aktivitas kolaboratif dalam terapi keluarga untuk mendapatkan hasil yang optimal pada individu-individu dalam keluarga. Dengan mengedepankan kolaboratif yang berbasis kompetensi, para terapis/konselor mengedepankan berbagai kekuatan, kemampuan dan sumber daya yang beragam untuk meningkatkan hasil terapi/konseling yang lebih baik dimasa-masa akan datang.

\section{PENTINGNYA KOLABORATIF}

Kolaboratif dilaksanakan di sekolah dengan alasan bahwa sekolah dan guru BK/konselor tidak bisa berfungsi sendiri/berdiri sendiri untuk memenuhi semua kebutuhan siswa. Pemenuhan kebutuhan siswa untuk mencapai kesuksesan tergantung pada usaha kolaborasi yang dilakukan oleh guru BK/konselor dengan pihak-pihak lain serta kegiatan kolaboratif yang dilakukan, tidak hanya bisa membantu siswa akan tetapi juga bisa membantu keluarga mereka (Dahir \& Stone, 2012:394). Lebih lanjut, Fields \& Hines (2010:250) guru BK/konselor baru bisa dikatakan profesional apabila mampu melakukan kolaborasi dan bekerja secara kelompok (collaboration \& teaming) secara tepat dengan berbagai pihak yang mendukung tercipta dan tercapainya kesuksesan siswa, baik itu dengan guru lain, siswa, orangtua bahkan dengan masyarakat yang lebih luas. Bahkan, Tang (2010:389) menyebutkan bahwa kolaborasi yang terjadi antar pihak yang berkepentingan dalam program pendidikan dan perkembangan siswa menjadi salah satu ciri sekolah yang efektif. Hal ini sejalan dengan pendapat Schmidt (2003) yang menyatakan bahwa konselor sekolah yang diharapkan ada pada masa sekarang dan akan datang adalah konselor sekolah yang bisa mengembangkan dan mendesain suatu program melibatkan orangtua dalam program pendidikan anaknya di sekolah melalui kegiatan kolaboratif. Pelibatan orantua yang dimaksud dapat berupa mengundang orangtua sebagai anggota komite sekolah, memberikan kesempatan kepada orangtua untuk menjadi tutor pada suatu program instruksional, keterlibatan orangtua dalam pendanaan program sekolah yang lebih luas serta dapat juga memperkuat pemahaman dan keterampilan orantua berkenaan dengan perkembangan anak dan orang dewasa.

Program bimbingan dan konseling komprehensif di sekolah mencakup aktifitas kolaborasi dalam hal pengembangan akademik, karir dan personal/sosial siswa. Aktifitas kolaborasi itu dilakukan dengan kolega di sekolah, orangtua, dan kolega di masyarakat yang lebih luas (Dollarhide \& Saginak, 2012:vi). Bentuk kolaborasi yang dilakukan dengan orangtua merupakan salah satu perwujudan komponen program dukungan sistem, yang digunakan untuk membantu mendukung komponen program pelayanan dasar, pelayanan responsif dan perencanaan individual untuk mencapai kemandirian dan perkembangan optimal siswa. Pelaksanaan program tersebut direncanakan untuk menjalankan fungsi konseling (counseling), koordinasi (coordinating) dan konsultasi (consulting) dalam kerangkan bimbingan dan konseling komprehensif (Dollarhide \& Saginak, 2012).

Berkenaan dengan kolaborasi dalam bimbingan dan konseling, penelitian yang dilakukan oleh Bryan (Young, 2013:2) memberikan makna bahwa proses kolaborasi yang dilakukan oleh konselor dengan berbagai pihak lain (termasuk orangtua) memberikan dampak pada tingginya motivasi siswa. Hal yang hampir sama juga disimpulkan oleh Grothaus \& Cole (2012:6) yang menyatakan bahwa kegiatan kolaboratif dengan pelibatan orangtua dalam pendidikan anaknya dapat meningkatkan munculnya potensi untuk sukses khususnya peningkatan motivasi, tingkat kehadiran, disiplin, penyelesaian tugas yang lebih baik dan meningkatkan kemungkinan untuk menamatkan pendidikan tepat waktu. Lebih lanjut, penelitian Brabeck, Walsh \& Latta (Dollarhide \& Saginak, 2012:163) menunjukkan bahwa dengan adanya kolaborasi antar kelompok (seperti sekolah, universitas, masyarakat dan profesi) dapat memberikan dampak yang positif terhadap motivasi akademik dan pengalaman siswa. Hal yang sama juga terjadi pada kolaborasi dengan administrator, guru, staf, paraprofesional, pupil services professionals dan orangtua yang memberikan pengaruh terhadap kesuksesan siswa di sekolah. Beberapa penelitian ini memberikan asumsi bahwa apabila siswa memiliki motivasi yang tinggi, meningkatnya kehadiran siswa, penyelesaian tugas yang lebih baik dan memiliki kemampuan untuk menamatkan pendidikan tepat waktu tentunya akan berpengaruh terhadap perkembangan karir siswa tersebut. Hal ini menunjukkan bahwa kegiatan kolaborasi dengan berbagai pihak (termasuk dengan orangtua) penting dilakukan oleh guru BK/konselor agar tercapainya tujuan pelayanan bimbingan dan konseling menuju perkembangan siswa yang mandiri dan optimal. Guru BK/konselor sebagai komponen utama kolaboratif hendaknya mampu membantu sekolah untuk memahami kebutuhan orangtua berkenaan dengan tanggung jawab pendidikan terhadap anaknya, mengumpulkan beberapa tujuan untuk meningkatkan keikutsertaan orangtua dan merancang strategi untuk mengembangkan hubungan yang lebih akrab dalam rangka keikutsertaan orangtua dalam aktivitas yang lebih luas (Schmidt, 2003:304). 


\section{PRINSIP-PRINSIP KOLABORATIF}

Friend \& Cook (Lee, 2013) menjelaskan bahwa prinsip kolaboratif hendaknya mengacu pada enam sifat yakni (1) kolaboratif bersifat sukarela, dimana antara komponen kolaboratif hendaknya melakukan kegiatan kolaboratif secara sukarela, tidak ada pemaksaan baik dari guru BK/konselor ke orangtua maupun kepada siswa, (2) kolaboratif didasarkan pada kesamaan/keseimbangan, dimana guru BK/konselor hendaknya meyakini bahwa semua individu yang berkontribusi memiliki nilai/keberartian yang sama dan seimbang, (3) kolaboratif dilaksanakan atas tujuan bersama, dimana tujuan tersebut dirumuskan dan akan dicapai secara bersama oleh guru $\mathrm{BK} /$ konselor dengan orangtua, (4) kolaboratif termasuk di dalamnya berbagi tanggung jawab untuk keputusan penting, hal ini berarti bahwa kegiatan kolaboratif tidak hanya menjadi dominasi satu orang saja, akan tetapi berbagi tanggung jawab, (5) kolaboratif berbagi akuntabilitas untuk hasil, dimana selain bertanggung jawab akan keputusan penting hendaknya guru Bk/konselor dan orangtua dalam kegiatan kolaboratif memiliki tanggung jawab akan akuntabilitas kegiatan yang disesuaikan dengan tujuan yang hendak dicapai, (6) kolaboratif hendaknya berbagai sumber, yang berarti bahwa antara komponen kolaboratif hendaknya saling mengisi, saling memberikan ilmu, memberikan informasi agar kesemuanya memiliki kemampuan yang hampir sama, dan (7) hendaknya kegiatan kolaboratif menjadi kegiatan yang ada dalam mencapai tujuan yang lebih baik dalam mencapai perkembangan siswa yang optimal

\section{BENTUK BIMBINGAN KONSELING KOLABORATIF}

Berbagai bentuk kolaboratif disajikan oleh beberapa ahli dalam usaha mencapai tujuan bimbingan dan konseling di sekolah. Diantaranya yang dikemukakan oleh Stone dan Dahir melalui CASTT a Wider net, Colllaboration Inclusion Models oleh Clark dan Bremen, serta Collaborative Culturally Competent Schools oleh Simcox, Nuijens dan Lee (Dollarhide \& Saginak, 2012:166-170).

1) Model CASST

Model CASTT yang merupakan akronim dari Community, Administrators, Students, Teachers, and Technology merupakan usaha kerjasama lebih luas yang dapat dilakukan oleh guru BK/konselor dengan masyarakat, administrator, siswa, guru dan teknologi untuk membantu siswa mencapai kesuksesan dan prestasi baik dalam bidang pribadi sosial, akademik maupun dalam bidang karir.

Lebih lanjut, dalam CASTT tersebut, Dahir \& Stone (2012:401) mengemukakan bahwa kerjasama dapat dilakukan dengan pihak di sekolah dan luar sekolah. Di pihak sekolah, guru BK/konselor dapat bekerjasama dengan (1) administrator, kolaborasi dengan para administrator dapat menguatkan tim kepemimpinan dalam sekolah. Hubungan antara guru BK/konselor dengan administrator dibutuhkan untuk mengetahui kebutuhan siswa dengan berbagai aktifitas seperti penyediaan informasi yang dibutuhkan berkenaan dengan data siswa yang lebih luas, saling berbagi data yang dibutuhkan untuk membangun program sekolah dan program BK yang saling melengkapi dan membantu terciptanya iklim sekolah yang kondusif untuk terciptanya kesuksesan; (2) guru lain, kerjasama yang baik dengan guru lain dapat membantu penguatan manajemen kelas, menciptakan kondisi yang nyaman bagi siswa, konsultasi, alih tangan kasus, promosi program dan perlakuan bagi siswa yang memerlukan perhatian khusus seperti remedial; (3) siswa, kerjasama dengan siswa dapat dilakukan dalam bentuk layanan teman sebaya seperti peer helper, peer facilitator, peer mediator, peer tutor dan peer supporters.

Di lingkungan luar sekolah, lebih lanjut Dahir \& Stone (2012:397) mengemukakan terdapat enam pihak yang dapat dimanfaatkan oleh guru BK/konselor dalam pelaksanaan kerjasama/kolaboratif yaitu dengan (1) orangtua, yang tidak hanya bisa menjadi sponsor utama berkenaan dengan masalah keuangan pelaksanaan program sekolah akan tetapi juga berperan lebih dalam membantu kesuksesan program bimbingan dan konseling sekolah, seperti sebagai tutor, mentor, konsultasi, berperan dalam kelompok bimbingan, berpartisipasi dalam kegiatan sekolah, serta dapat juga suatu ketika dijadikan objek layanan untuk membantu ketercapaian tujuan program; (2) profesi kemanusiaan lainnya, kerja sama dapat dilakukan untuk mencapai kesuksesan akademik siswa dan juga dapat mempengaruhi orangtua untuk bisa membantu siswa mencapai kesuksesan akademiknya; (3) kelompok/rukun tetangga, kelompok ini juga bisa dimanfaatkan oleh guru BK/konselor untuk mencapai kesuksesan pelaksanaan program yang biasanya berminat dalam hal yang berkaitan dengan pendidikan, housing, rekreasi dan peningkatan/kemajuan 
masyarakat yang lebih luas. Hal ini juga mengisyaratkan bahwa lingkungan masyarakat disekitar yang mendukung perkembangan anak akan menjadi modal penting dalam usaha pencapaian perkembangan optimal anak; (4) perusahaan, kerjasama dapat dilakukan dalam usaha pendidikan dan latihan berkenaan dengan karir. Selain itu perusahaan dapat diminta pertolongan untuk mendukung secara finansial (sponsor) kegiatan sekolah; (5) perguruan tinggi, kerjasama dapat dilakukan dalam hal pendidikan dan latihan baik bagi siswa maupun bagi peningkatan kompetensi guru BK/konselor dalam bentuk magang, praktikum dan berbagi pengalaman. Kegiatan lain yang dapat dilakukan adalah kerjasama dalam penelitian untuk mengukur pengaruh program yang diterima siswa; (6) alumni, kerjasama dapat dilakukan salah satunya dengan mengundang alumni berbagi pengalaman mereka terhadap berbagai karir dan pengalaman hidup yang dijalaninya untuk dibagi kepada siswa sehingga mereka memiliki pemahaman baru berkenaan dengan pekerjaan dan dapat juga memberi dampak pada motivasi belajar siswa untuk mencapai kesuksesan akademiknya.

2) Collaborative inclusion model

Clark dan Bremen menciptakan model kolaboratif untuk konselor dan guru yang merepresentasikan berbagai praktik konsultasi. Model ini merekomendasikan Enam langkah inklusif dalam proses intervensi dimana guru dan konselor secara bersama merencanakan, mengimplementasikan dan mengevaluasi semua intervensi dalam ruang kelas dimana semua siswa bisa memperoleh manfaat. Enam langkah yang direkomendasikan itu adalah (a) klien dapat diperoleh dari alihtangan guru, administrator, orangtua atau atas inisiatif sendiri oleh siswa yang bersangkutan untuk mendapatkan layanan oleh konselor, (b) indentifikasi masalah dengan memperoleh dan menggali informasi dari berbagai catatan, berbicara dengan mitra seperti guru, orangtua dan administrator, (c) merencanakan intervensi dalam kelas untuk mencari jawaban atas tujuan yang akan dicapai secara bersama, (d) melaksanakan intervensi dan memodifikasinya sebagai kebutuhan. Langkah ini juga termasuk di dalamnya infusi melalui tutor/mentor sebaya untuk memberikan dukungan kepada siswa yang berkelanjutan, (e) mengembangkan sebuah rencana untuk membiarkan guru dan siswa untuk menindaklanjuti kegiatan setelah konselor menyelesaikan intervensi dalam ruang kelas. Pada tahap ini termasuk di dalamnya adalah memberikan penguatan, sistem umpan balik dan diikuti dengan panduan-panduan yang memungkinkan, dan (f) evaluasi dan monitor intervensi. Konselor dapat melakukan pengawasan kepada guru dan siswa secara periodik atau observasi terhadap pelaksanaan intervensi dalam ruang kelas.

3) Collaborative Culturally Competent Schools

Model ini dikembangkan oleh Simcox, Nuijens dan Lee dengan mengemukakan sebuah model kolaboratif yang sensitif secara kultural dan ekologis antara konselor sekolah dan psikolog sekolah untuk meningkatkan kompetensi budaya di sekolah. Model ini mengedepankan hubungan kerjasama antara konselor sekolah dan psikolog sekolah dalam mengembangkan, melaksanakan, dan mengevaluasi segala tindakan pada empat tingkatan utama pelayanan terhadap siswa, orangtua dan keluarga, pendidik dan masyarakat. Berikut disajikan secara ringkas ke empat tingkatan yang dimaksud yaitu : (a) Intervensi yang berpusat pada siswa, merupakan bentuk intervensi yang dilakukan terhadap siswa dengan memfasilitasi siswa untuk sukses dalam bidang akademik, pribadi-sosial, dan karir melalui intervensi individual, kelompok kecil dan konsultasi; (b) penguatan keluarga, intervensi pada tingkatan ini fokus pada penguatan peran keluarga melalui berbagai penyajian topik dan forum pertemuan termasuk dalamnya topik yang berkenaan dengan kurikulum sekolah, asesmen dan penempatan, hubungan antara guru dan orangtua dan pendidikan administrasi; (c) konsultasi kolegial, tingkatan ini bertujuan untuk menciptakan kesempatan pengembangan profesional bagi staf pendidik dan profesional dengan cara mempromosikan sensitivitas budaya, respon dan kompetensi sekolah. Workshop dan seminar dapat dilakukan untuk menciptakan kompetesi dalam praktik dan strategi pendidikan; (d) pemanfaatan sumber komunitas, sekolah dan masyarakat dapat bekerjasama untuk mencapai kesuksesan sekolah pada khususnya dan pendidikan pada umumnya. Kolaborasi pada tingkatan ini dapat berupa peningkatan kesadaran masyarakat terhadap program sekolah dan pendidikan serta dapat juga secara bersama mengembangkan program pendidikan berbasis kemasyarakatan. 


\section{SIMPULAN DAN SARAN}

Pembahasan di atas menunjukkan pentingnya pelaksanaan kolaboratif dengan berbagai pihak sebagai salahsatu kerangka acuan pelaksanaan bimbingan dan konseling di sekolah. Beberapa model yang dikemukakan oleh para ahli menunjukkan bahwa kolaboratif sebagai usaha bersama yang dilakukan antara guru BK/konselor dan orang lain yang hendaknya mampu diimplementasikan dengan menerapkan fungsi-fungsi manajemen program bimbingan kolaboratif. Hal ini dikemukakan oleh Gysbers \& Henderson (dalam Dahir \& Stone, 2012:303) yang menyatakan perlu adanya perencanaan (planning), perancangan (designing), pelaksanaan (implementing), dan evaluasi (evaluating) secara bersama dengan berbagai pihak dalam penyusunan program bersama bimbingan sehingga tujuan yang telah dirumuskan secara bersama dapat dicapai secara sukses dan tepat. Selain dalam manajemen program, guru BK/konselor dapat memberikan layanan langsung ke komponen yang diajak untuk melakukan kegiatan kolaboratif, yang nantinya diharapkan berpengaruh terhadap pelaksanaan program secara keseluruhan yang telah direncanakan, yang pada akhirnya berdampak pada siswa. Bentuk layanan langsung yang dapat diberikan oleh guru BK/konselor adalah dengan konseling individual, bimbingan dan konseling kelompok, konsultasi dan kegiatan-kegiatan lain seperti workshop berkenaan dengan topik yang mendukung pelaksanaan program, dan bentuk kegiatan lainnya. Untuk itu, guru BK/konselor dapat mengundang berbagai pihak tersebut (orangtua dan lainnya) ke sekolah untuk membicarakan lebih lanjut program bersama dalam usaha mencapai perkembangan siswa. Program yang dimaksud adalah program kolaboratif yang disusun berdasarkan kebutuhan siswa, orangtua dan guru, dilaksanakan secara bersama sesuai dengan peran dan tanggung jawab masing-masing komponen serta dilaksanakan secara aktif, sukarela dan penuh pertanggungjawaban.

\section{DAFTAR RUJUKAN}

Bertolino, B. \& O'Hanlon, W.H. (2002). Collaborative, competency-based counseling and therapy. Boston: Allyn and Bacon.

Dahir, C. A., \& Stone, C.B. (2012). The transformed school counselor. USA: Brooks/Cole Cencage Learning

Depdiknas. (2008). Penataan pendidikan profesional konselor dan layanan bimbingan dan konseling dalam jalur pendidikan formal. Jakarta: Dirjen Dikti Depdiknas.

Dollarhide, C. T. \& Saginak, K. A. (2012). Comprehensive school counseling programs. New Jersey: Pearson Education Inc.

Frans \& Bursuck W. (1996). Including student with special needs. Boston

Gladding, S. T. (2012). Konseling profesi yang menyeluruh (Alih Bahasa P.M. Winarno dan Lilian Yuwono). Jakarta: Indeks.

Grothaus, T., \& Cole, R. (2012). Meeting the challenges together: school counselor collaborating with students and families with low income. Old Dominion University.

Keys, S.G., dkk. (1998). Collaborative consultant: A new role for counselors serving at-risk youths. Journal of Counseling and Development, 76 (2), hlm. 123-133.

Lee, H. (2012). Collaboration: a must for teachers in inclusive educational settings [Online]. Tersedia di: http://education.shu.edu/pt3grant/lee/collaboration.html Di akses 19 Mei 2013.

Lusky, M.B., \& Hayes, R.L. (2001). Collaborative consultation and program evaluation. Journal of Counseling and Development, 79 (1), hlm. 26-38.

Memmott, J. (1998). Collaborative practice in family therapy. Journal of Marital and Family Therapy, 24 (3), hlm. 393-396.

Phillippo, K., \& Stone, S. (2006). School-based collaborative teams: an exploratory study of tasks and activities. Children \& Schools Journal, 28 (4), hlm. 229-235. 
Schmidt, J.J. (2003). Counseling in schools, essential services and comprehensive programs (Fourth edition). USA: Pearson Education Inc.

Tang, M. (2010). Assesing and changing school culture. Dalam B.T. Erford (Penyunting), Profesional school counseling, a handbook of theories, program \& practices (hlm 387-398). Texas: Pro Ed.

Tersedia di: http://bebex-cuex.blogspot.com, peranan orangtua terhadap pendidikan anak. Diakses 26 Mei 2013

Tersedia di: http://kompasiana.com, isu-isu pendidikan. Di akses 17 Januari 2013

Young, A.A., dkk. (2013). Enhancing school counselor instructional leadership through collaborative teaming: implications for principals. NASSP Buletin, XX (X), hlm. 1-17. 